
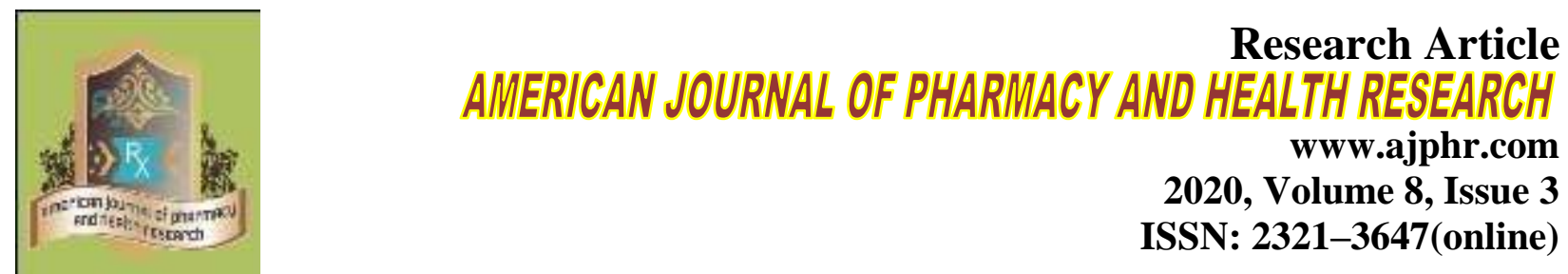

2020, Volume 8, Issue 3

ISSN: 2321-3647(online)

\title{
Development of New Validated RP-HPLC Method for Estimation of Anastrazole in Bulk and Tablet Dosage Forms
}

\author{
Y.Omini*, R.B. Desireddy, A.Anil Kumar, B.Tarun Kumar, CH. Anand Kumar, CH. \\ Srinivas Rao.
}

Nalanda Institute of Pharmaceutical Sciences, Siddharth Nagar, Kantepudi (V), Sattenapalli

(M), Guntur (DT) - 522438

\begin{abstract}
A simple, Precised, Accurate method was developed for the estimation of Anastrozole by RPHPLC technique. Chromatographic conditions used are stationary phase Azilent C18 (150mm x 4.6mm, $5 \mu \mathrm{m}$ ) Mobile phase $0.01 \mathrm{~N} \mathrm{Kh2Po4:Acetonitrile} \mathrm{in} \mathrm{the} \mathrm{ratio} \mathrm{of} \mathrm{60:40} \mathrm{and} \mathrm{flow} \mathrm{rate} \mathrm{was}$ maintained at $1.0 \mathrm{ml} / \mathrm{min}$, detection wave length was $215 \mathrm{~nm}$, column temperature was set to $30^{\circ} \mathrm{C}$ and diluent was mobile phase Conditions were finalized as optimized method. The retention time was found to be $2.248 \mathrm{~min}$. System suitability parameters were studied by injecting the standard six times and results were well under the acceptance criteria. Linearity study was carried out between $25 \%$ to $150 \%$ levels, $\mathrm{R}^{2}$ value was found to be as 0.999 . Precision was found to be 0.5 for repeatability and 0.6 for intermediate precision. LOD and LOQ are $0.086 \mu \mathrm{g} / \mathrm{ml}$ and $0.261 \mu \mathrm{g} / \mathrm{ml}$ respectively. By using above method assay of marketed formulation was carried out $100.11 \%$ was present. Degradation studies of Anastrozole were done, in all conditions purity threshold was more than purity angle and within the acceptable range. Full length method was not performed; if it is done this method can be used for routine analysis of Anastrozole.
\end{abstract}

Keywords: HPLC Anastrozole, Method development, ICH Guidelines. 


\section{INTRODUCTION}

Anastrozole is a non-steroidal aromatase inhibitor (AI), similar to Letrozole, used to decrease circulating estrogen levels in the treatment of postmenopausal women with estrogen-responsive breast cancer. Anastrozole was first approved for use in the United States in 1995. Anastrozole is also related to exemestane, a steroidal AI, but its non-steroidal nature provides stark advantages including a lack of steroid-associated adverse effects such as weight gain and acne. Aromatase inhibitor, including Anastrozole, have become endocrine drugs of choice in the treatment of postmenopausal breast cancer due to a more favourable efficacy and adverse effect profile as compared to earlier estrogen receprtor modulators such as tamoxifen.

\section{Structure of Anastrozole:}

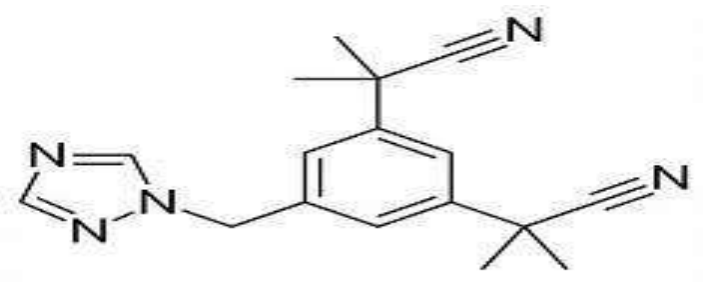

\section{MATERIALS AND METHOD}

\section{Materials:}

Anastrozole pure drugs (API), Combination Anastrozole tablets (Arimidex), Distilled water, Acetonitrile, Phosphate buffer, Methanol, Potassium Dihydrogen Ortho Phosphate buffer, OrthoPhosphoric acid. All the above chemicals and solvents are from Rankem.

\section{Equipment and Apparatus used:}

HPLC instrument used was of WATERS HPLC 2695 SYSTEM with Auto Injector and PDA Detector. Software used is Empower. UV-VIS spectrophotometer PG Instruments T60 with special bandwidth of $2 \mathrm{~mm}$ and $10 \mathrm{~mm}$ and matched quartz was be used for measuring absorbance for Anastrozole solutions.

- Sonicator (Ultrasonic sonicator)

- $\quad$ PH meter (Thermo scientific)

- Micro balance (Sartorius)

- Vaccum filter pump

\section{Reagents used:}

- Methanol HPLC Grade (RANKEM)

- Acetonitrile HPLC Grade (RANKEM)

- $\quad$ HPLC Grade Water (RANKEM) 
- Glacial Acetic acid

\section{Preparation of 0.01N Potassium Dihydrogen Phosphate Buffer:}

Accurately weighed 1.36gms of Potassium Dihydrogen Ortho Phosphate in 1000ml of volumetric flask add about $900 \mathrm{ml}$ of milli-Q water added and degas to sonicate and finally make up the volume with water then add $1 \mathrm{ml}$ of Triethylamine then $\mathrm{P}^{\mathrm{H}}$ was adjusted to 3.0 with diluted Ortho Phosphoric acid solution.

\section{Preparation of Mobile Phase}

Into a 1000ml cleaned volumetric flask, HPLC grade, Acetonitrile 400ml and Potassium Dihydrogen Phosphate $(0.01 \% \mathrm{w} / \mathrm{v})$ which are filtered through $0.25 \mathrm{~mm}$ membrane filters by vaccum filtration were slowly added, mixed well and Sonicated upto 20min. Cool the above solution. This solution is again Sonicated to $10 \mathrm{~min}$. Cool the solution in room temperature and used for chromatography method

\section{Preparation of Standard stock solutions:}

Accurately weighed $5 \mathrm{mg}$ of Anastrozole transferred $50 \mathrm{ml}$ of volumetric flask, and $3 / 4^{\text {th }}$ of diluents was added and Sonicated for 10 minutes. Flasks were made up with diluents and labeled as Standard stock solution $(100 \mu \mathrm{g} / \mathrm{ml}$ of Anastrozole $)$

\section{Preparation of Standard working solutions (100\% solution):}

$1 \mathrm{ml}$ of Anastrozole each stock solution was pipetted out and taken into a $10 \mathrm{ml}$ volumetric flask and made up with diluents $(10 \mu \mathrm{g} / \mathrm{ml}$ of Anastrozole).

\section{Preparation of Sample stock solution:}

5 tablets were weighed and the average weight of each tablet was calculated, then the weight equivalent to 1 tablet was transferred into a $10 \mathrm{ml}$ of volumetric flask, $5 \mathrm{ml}$ of diluents was added and Sonicated for 25min, further the volume was made up with diluent and filtered by HPLC filters $(100 \mu \mathrm{g} / \mathrm{ml}$ of Anastrozole).

\section{Preparation of Sample working solutions (100\% solution):}

$1 \mathrm{ml}$ of filtered sample stock solution was transferred to $10 \mathrm{ml}$ volumetric flask and made up with diluent $(10 \mu \mathrm{g} / \mathrm{ml}$ of Anastrozole $)$.

\section{RP-HPLC METHOD DEVELOPMENT}

Based on nature and solubility characteristics of Anastrozole, Reverse phase mode of HPLC was selected for chromatography. Among different RP-HPLC stationary phases tried, C18 column was found to be optimum. In order to get sharp peak with base line separation from interfering peaks carried out a number of experiments by varying the composition of solvents and mobile phase flow rate. To have an ideal separation of drug under isocratic conditions, mixtures of 
solvents like Methanol, water and Acetonitrile with or without different buffers in different combinations were tested as mobile phase. A mixture of 0.01N KH2PO4 : Acetonitrile (60:40 $\mathrm{v} / \mathrm{v})$ was proved to be the most suitable of all the combinations, since the chromatographic peak obtained was better defined and resolved and almost free from tailing. This chromatographic conditions for the estimation of Anastrozole was discussed in below table.

Table 1: Optimized chromatographic conditions for estimation of Anastrozole

\begin{tabular}{ll}
\hline Parameter & Condition \\
\hline Mobile phase & $0.01 \mathrm{~N} \mathrm{KH} 2 \mathrm{PO} 4:$ Acetonitrile $(60: 40)(\mathrm{V} / \mathrm{V})$ \\
Pump mode & Isocratic \\
Diluents & Mobile phase \\
Column & Azilent C18 Column $(150 \times 4.6 \mathrm{~mm}, 5 \mu)$ \\
Column Temp & $30^{0} \mathrm{C}$ \\
Wavelength & $215 \mathrm{~nm}$ \\
Injection Volume & $10 \mu \mathrm{L}$ \\
Flow rate & $1.0 \mathrm{ml} / \mathrm{min}$ \\
Run time & $10 \mathrm{~min}$ \\
\hline
\end{tabular}

\section{RESULTS AND DISCUSSION}

\section{Analysis of formulations:}

The sample solution was injected and a chromatogram was recorded. The injections were repeated five times and the peak areas were recorded. The amount of drug present in the pharmaceutical formulation was calculated using standard calibration curve (concentration in $\mu \mathrm{g} / \mathrm{ml}$ was taken on $\mathrm{X}$-axis and average peak area on $\mathrm{Y}$-axis). A representative chromatogram has been given in Fig. 1

\section{VALIDATION OF PROPOSED METHOD}

As an integral part of analytical method development is validation. The proposed method was validated as per ICH guidelines. 


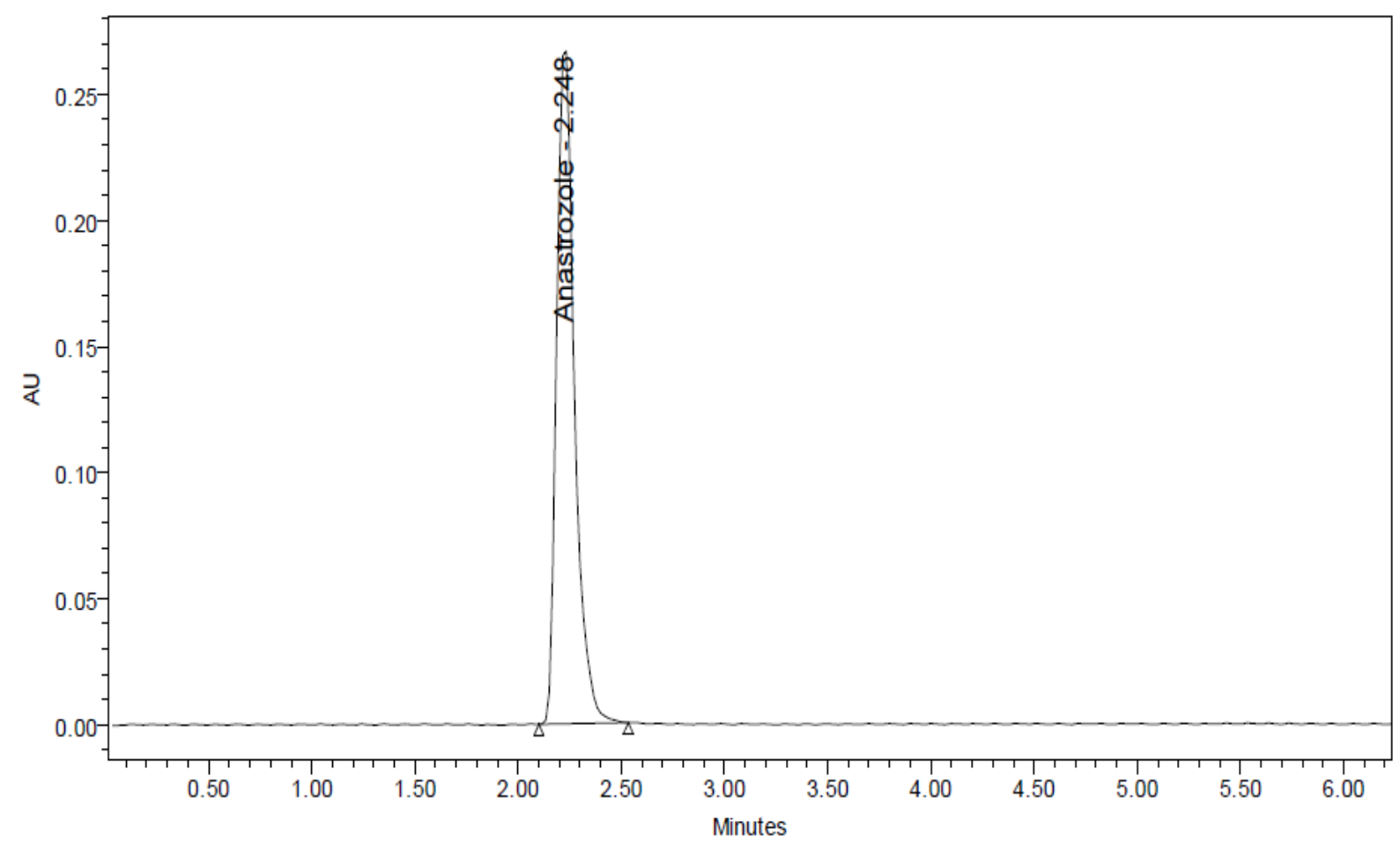

Chromatogram of Anastrozole

\section{Linearity}

To demonstrate the linearity of assay method, inject 6 standard solutions with concentrations of about $2.5 \mathrm{ppm}$ to $15 \mathrm{ppm}$ of Anastrozole. Plot a graph to concentration versus peak area. Slope obtained was 10820 Y-Intercept was 395.02 and Correlation Co-efficient was found to be 0.999 and Linearity plot was shown in table

\section{Table 2: Linearity Results of Anastrozole}

\begin{tabular}{lll}
\hline $\begin{array}{l}\text { Linearity } \\
\text { Level }(\%)\end{array}$ & $\begin{array}{l}\text { Concentration } \\
\text { (ppm) }\end{array}$ & Area \\
\hline 0 & 0 & 0 \\
25 & 2.5 & 27433 \\
50 & 5 & 54057 \\
75 & 7.5 & 82554 \\
100 & 10 & 108660 \\
125 & 12.5 & 135956 \\
150 & 15 & 161446 \\
\hline
\end{tabular}




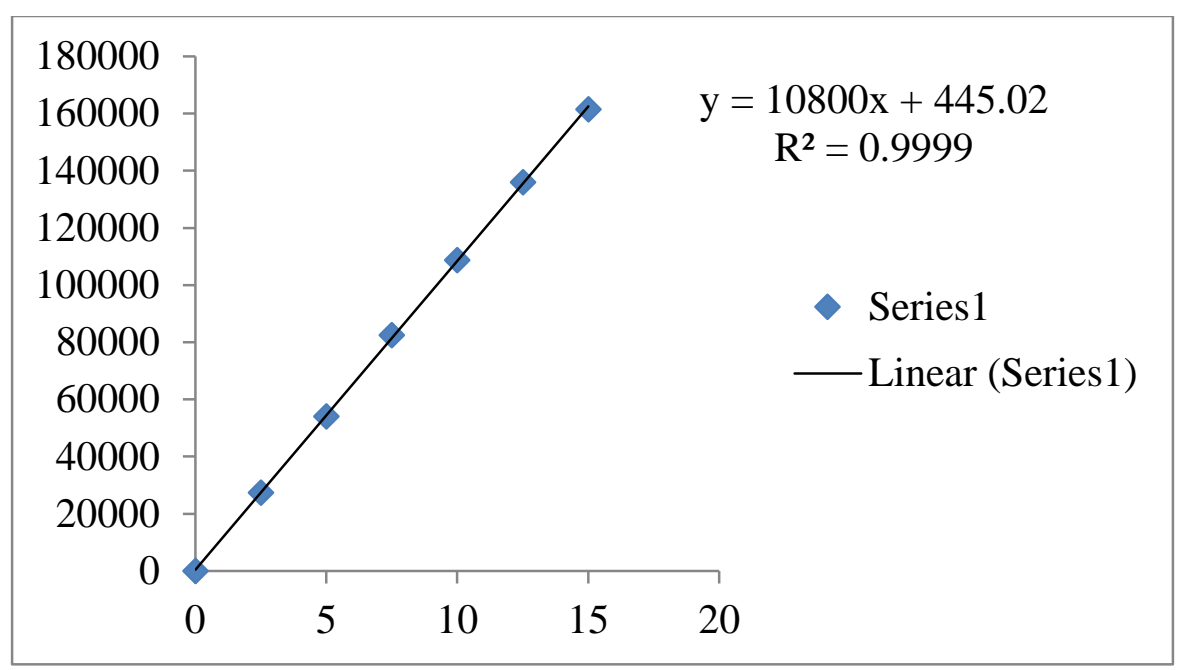

\section{Linearity Plot}

\section{Precision:}

\section{Repeatability:}

Six working sample solutions of $10 \mathrm{ppm}$ are injected and the $\%$ Amount found was calculated and $\%$ RSD was found to be $\underline{1.0}$

Table 3. Repeatability data

\begin{tabular}{ll}
\hline S.No & Peak Area \\
\hline 1 & 106637 \\
2 & 104967 \\
3 & 105889 \\
4 & 105829 \\
5 & 105479 \\
6 & 105552 \\
AVG & 105726 \\
STDEV & 554.0 \\
\%RSD & 0.5 \\
\hline
\end{tabular}




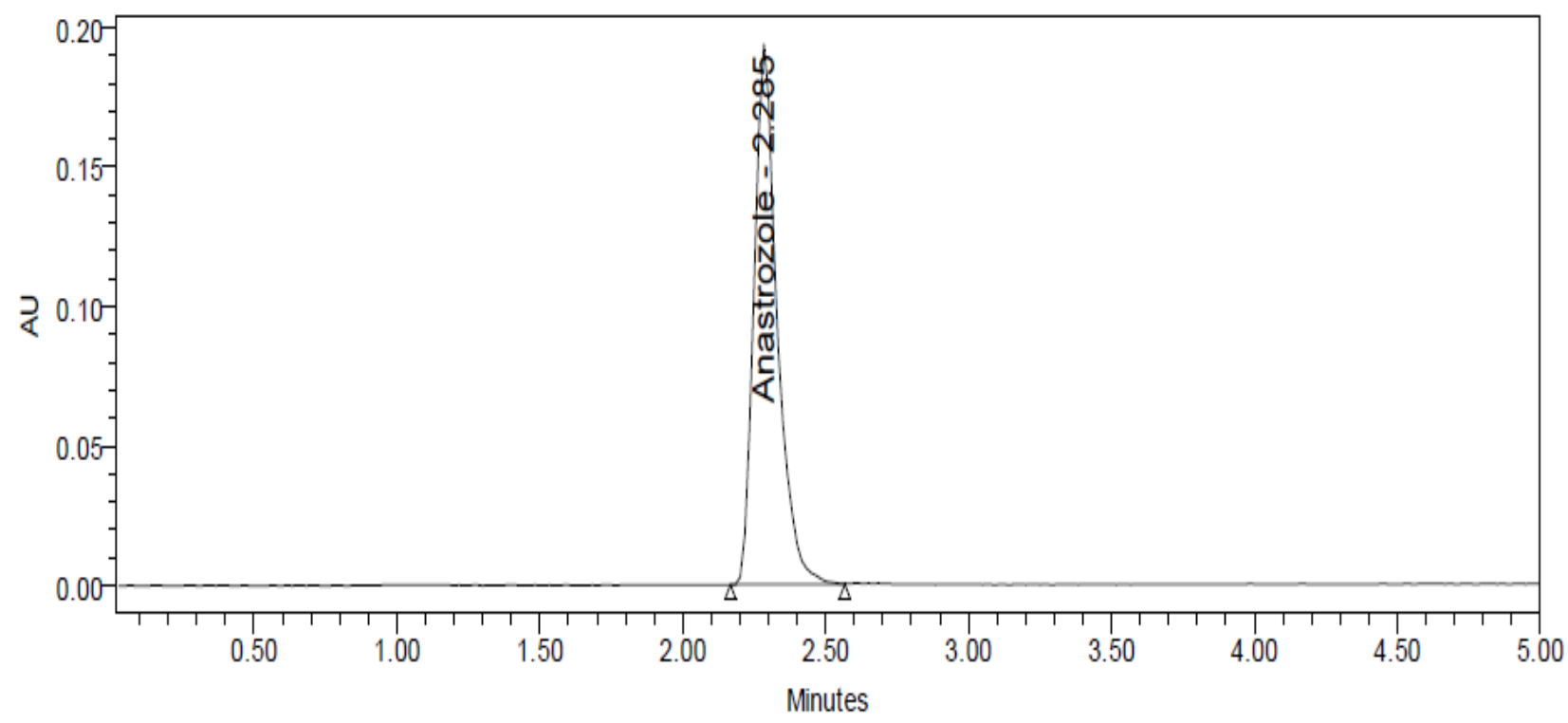

\section{Intermediate precision:}

Five working sample solutions of 10ppm are injected on the next day of the preparation of samples and the \% Amount found was calculated and \%RSD was found to be $\underline{1.0}$

Table 4. Intermediate precision data

\begin{tabular}{ll}
\hline S.No & Peak Area \\
\hline 1 & 102214 \\
2 & 102481 \\
3 & 103878 \\
4 & 102095 \\
5 & 103011 \\
6 & 102693 \\
AVG & 102729 \\
STDEV & 652.6 \\
\%RSD & 0.6 \\
\hline
\end{tabular}

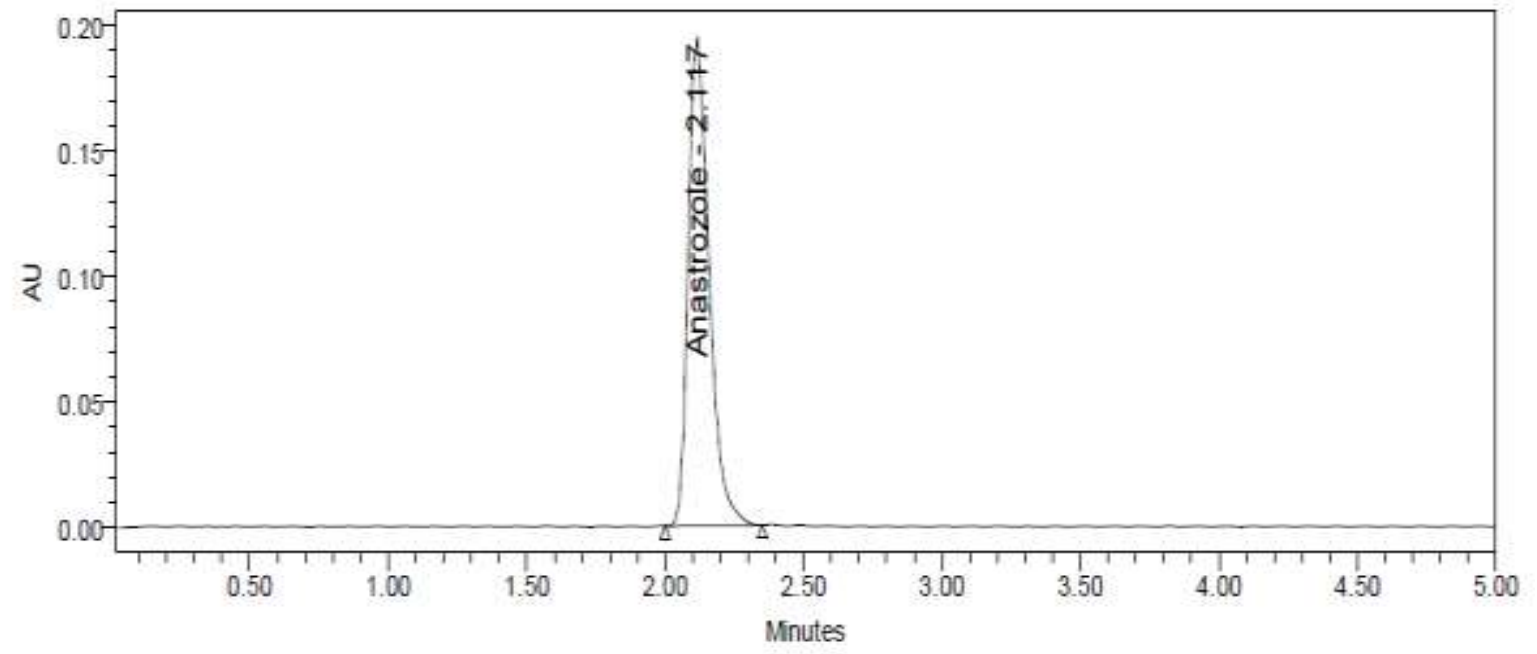




\section{Limit of Detection and Limit of Quantification:}

Calibration curve was prepared using concentrations in the range of $2.5-12.5 \mu \mathrm{g} / \mathrm{ml}$ (expected detection limit range). The standard deviation of $\mathrm{Y}$-intercepts of regression line was determined and kept in following equation for the determination of Detection limit and Quantitation limit. The results were reported in table 3.

Limit of detection $\quad=\sigma \times 3.3$

$$
\begin{array}{ll}
\frac{\mathrm{S}}{2} & \\
\text { Limit of quantification } & =\quad \times 10
\end{array}
$$

Where,

$\sigma=$ the standard deviation of the response.

$\mathrm{S}=$ the slope of the calibration curve

Table 5. Limit of Detection and Limit of Quantification for Anastrozole

\begin{tabular}{ll}
\hline S & Values \\
\hline Limit of & $0.261 \mu \mathrm{g} / \mathrm{ml}$ \\
$\begin{array}{l}\text { Quantification } \\
\text { Limit of Detection }\end{array}$ & $0.086 \mu \mathrm{g} / \mathrm{ml}$
\end{tabular}

LOD: Detection limit of the Anastrozole in this method was found to be $0.086 \mu \mathrm{g} / \mathrm{ml}$.

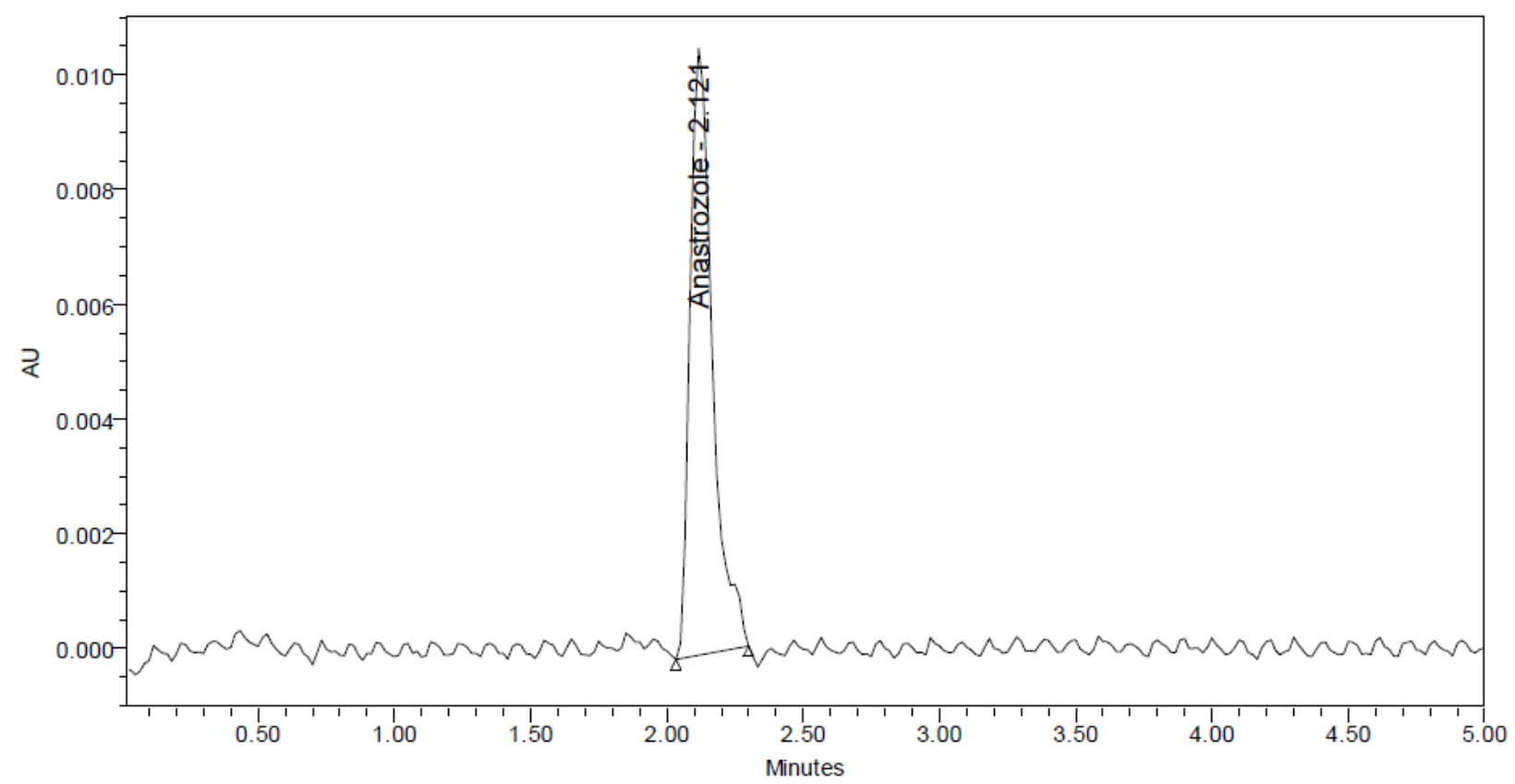

Figure LOD Chromatogram of Anastrozole

LOQ: Quantification limit of the Anastrozole in this method was found to be $0.261 \mu \mathrm{g} / \mathrm{ml}$. 


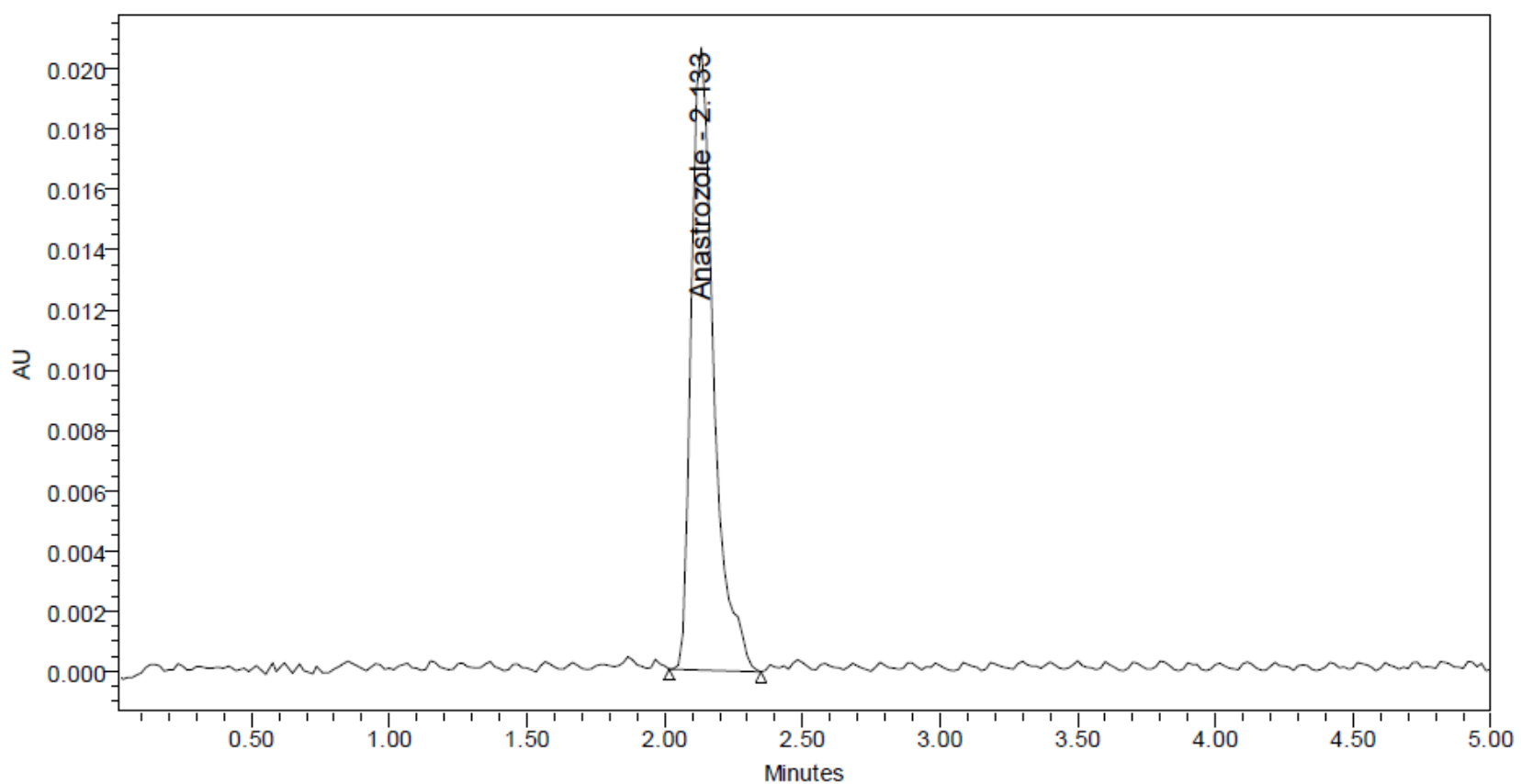

Figure LOQ Chromatogram of Anastrozole

\section{Accuracy:}

Three Concentrations of 50\%, 100\%, 150\% are Injected in a triplicate manner and \% Recovery was calculated as $100.26 \%$.

Table 6: Accuracy data

\begin{tabular}{lllll}
\hline \% Level & $\begin{array}{l}\text { Amount } \\
\text { Spiked }(\boldsymbol{\mu g} / \mathbf{m L})\end{array}$ & $\begin{array}{l}\text { Amount } \\
\text { recovered }(\boldsymbol{\mu g} / \mathbf{m L})\end{array}$ & \% Recovery & $\begin{array}{c}\text { Mean } \\
\text { \% Recovery }\end{array}$ \\
\hline $50 \%$ & 5 & 5.04122 & 100.82 & $100.20 \%$ \\
& 5 & 4.96414 & 99.28 & \\
$100 \%$ & 5 & 5.047043 & 100.94 & \\
& 10 & 9.951109 & 99.51 & \\
$150 \%$ & 10 & 10.08401 & 100.54 & \\
& 15 & 9.915434 & 99.15 & \\
& 15 & 14.9427 & 99.62 & \\
\hline
\end{tabular}




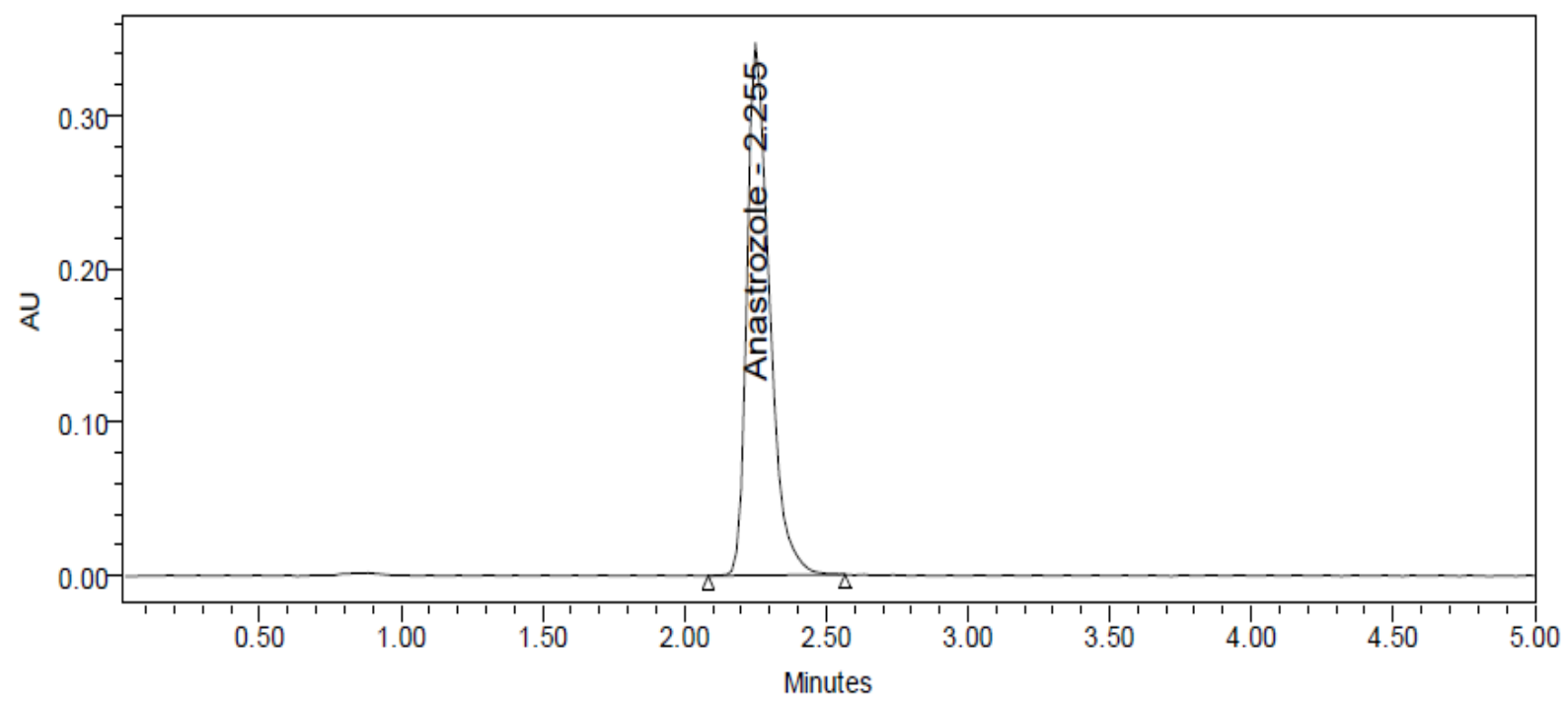

\section{Robustness:}

Small Deliberate change in the method is made like Flow minus, flow plus, Mobile phase minus, Mobile phase plus, Temperature minus, Temperature Plus. \%RSD of the above conditions is calculated

Table 7: Robustness Data

\begin{tabular}{ll}
\hline Parameter & \%RSD \\
\hline Flow Minus (0.9misin) & 1.0 \\
Flow Plus(1.1ml/min) & 1.4 \\
Mobile phase Minus (50B:50A) & 0.8 \\
Mobile phase Plus (40B:60A) & 1.4 \\
Temperature minus $\left(25^{\circ} \mathrm{C}\right)$ & 1.3 \\
Temperature plus $\left(35^{\circ} \mathrm{C}\right)$ & 1.1 \\
\hline
\end{tabular}

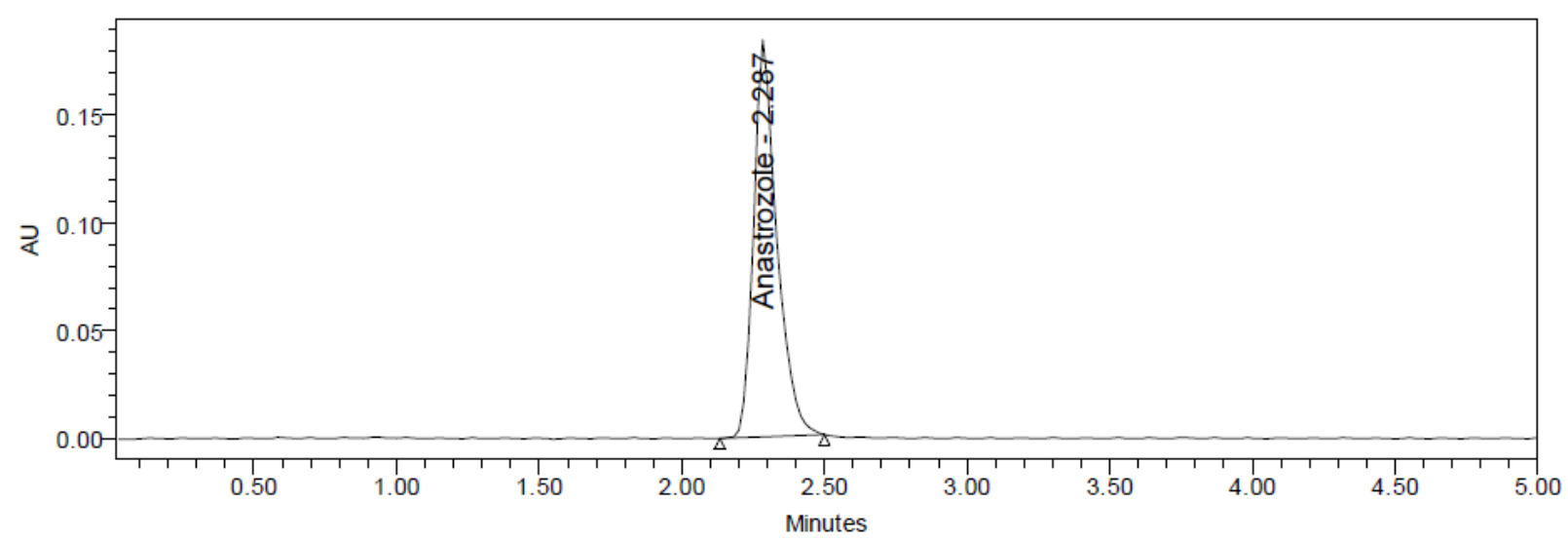




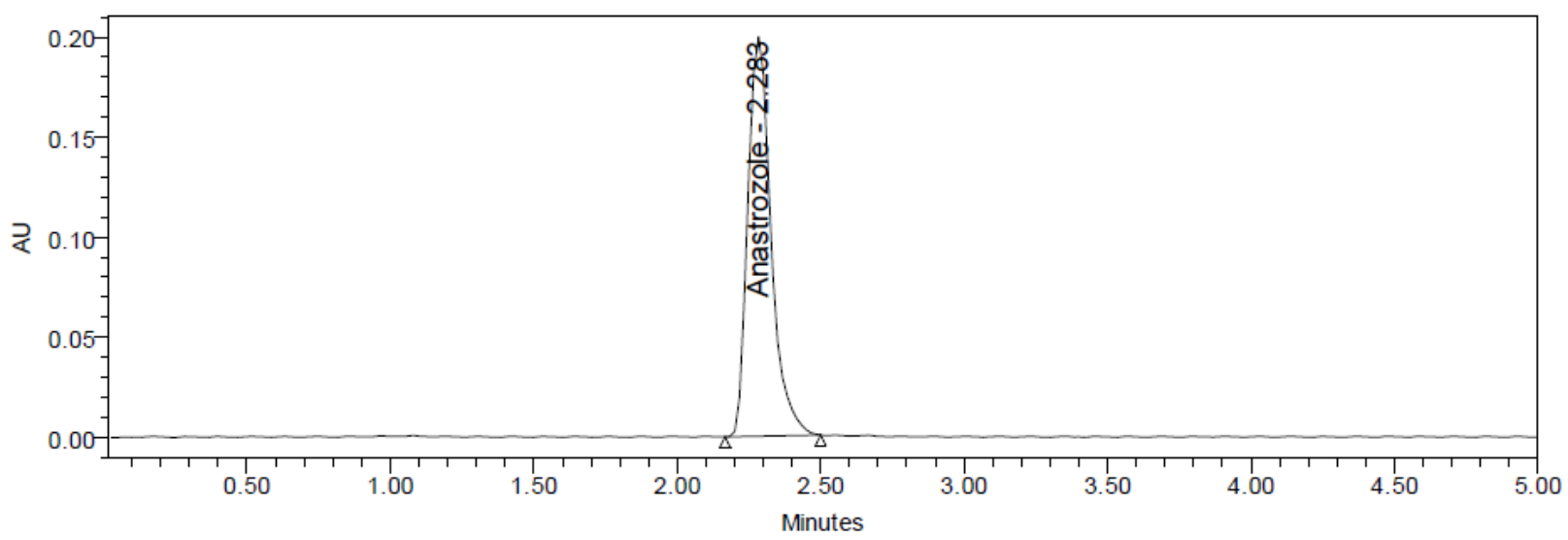

\section{Assay of Marketed Formulation}

Standard solution and sample solution were injected separately into the system and chromatograms were recorded and drug present in sample was calculated using before mentioned formula.

Table 8: Assay of Formulation

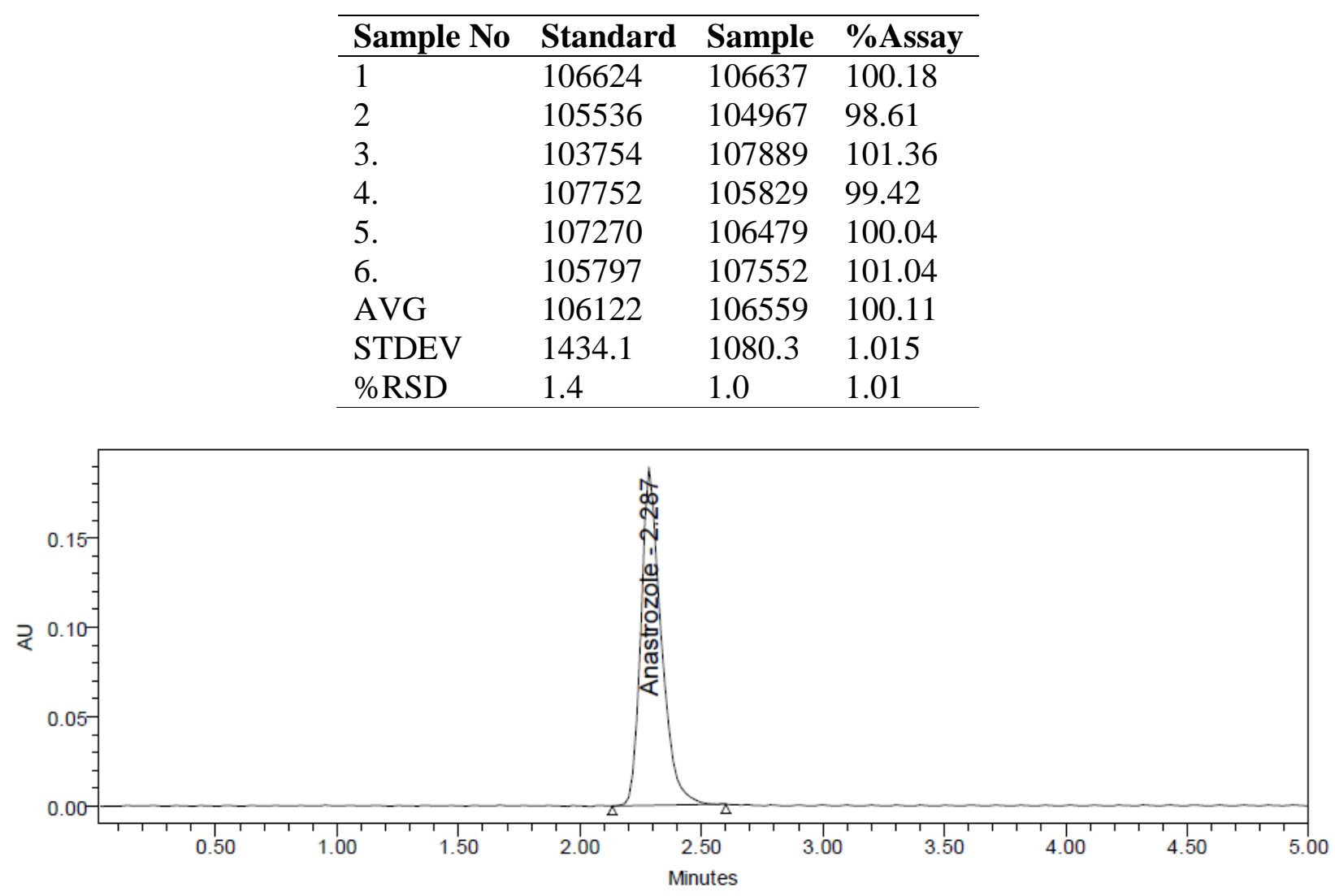




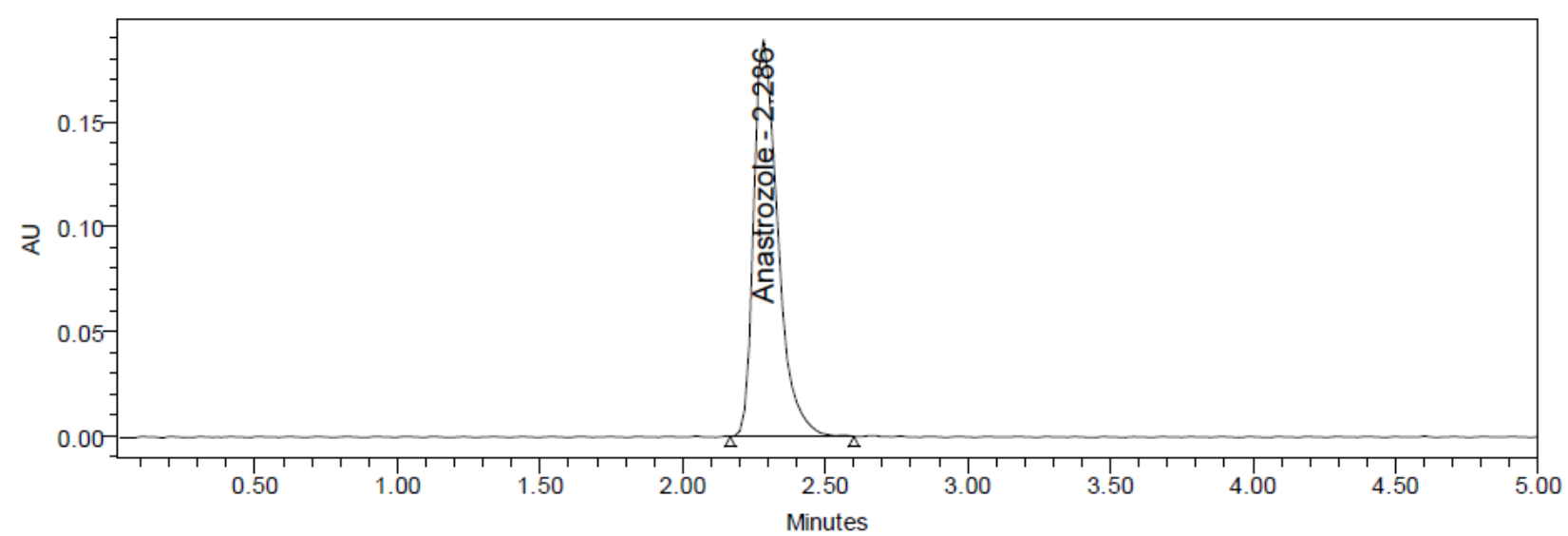

\section{System Suitability}

A Standard solution of Anastrozole working standard was prepared as per procedure and was injected five times into the HPLC system. The system suitability parameters were evaluated from standard Chromatograms obtained by calculating the \% RSD of retention time, tailing factor, theoretical plates and peak areas from five replicate injections are within range and Results were shown in table

Table 9: System Suitability Parameters

\begin{tabular}{llll}
\hline S no & \multicolumn{2}{l}{ Anastrozole } & \\
Inj & RT(min) & SP Plate Count & Tailing \\
\hline 1 & 2.274 & 3725 & 1.45 \\
2 & 2.276 & $4031 \mathrm{U}$ & 1.37 \\
3 & 2.282 & 3923 & 1.41 \\
4 & 2.284 & 3411 & 1.35 \\
5 & 2.286 & 3427 & 1.43 \\
6 & 2.287 & 3495 & 1.3 \\
\hline
\end{tabular}

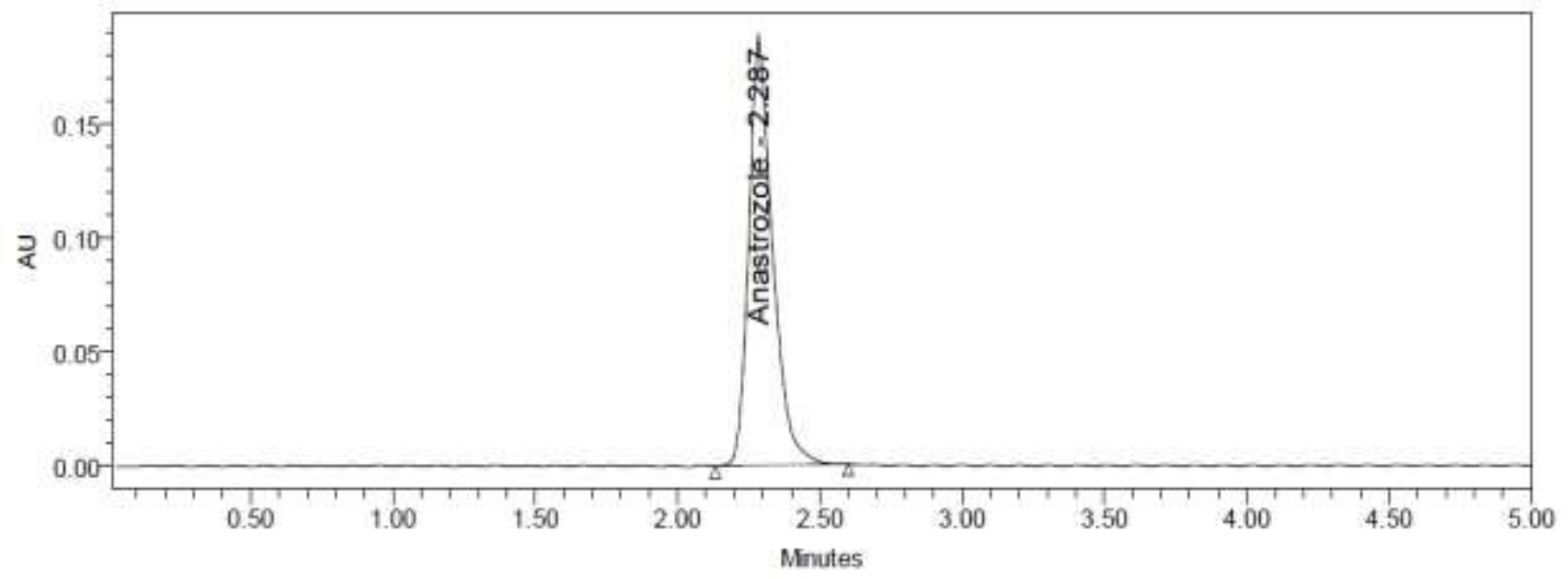

\section{Degradation Studies:}


Degradation studies were performed with the formulation and the degraded samples were injected. Assay of the injected samples was calculated and all the samples passed the limits of degradation

\section{Degradation procedure:}

\section{Oxidation:}

To $1 \mathrm{ml}$ of stock solution ofAnastrozole $1 \mathrm{ml}$ of $20 \%$ hydrogen peroxide $(\mathrm{H} 2 \mathrm{O} 2)$ was added separately. The solutions were kept for $30 \mathrm{~min}$ at $60^{\circ} \mathrm{c}$. For HPLC study, the resultant solution was diluted to obtain $(10 \mathrm{ppm})$ solution and10 $\mu$ lwere injected into the system and the chromatograms were recorded to assess the stability of sample.

\section{Acid Degradation Studies:}

To $1 \mathrm{ml}$ of stock solution Anastrozole $1 \mathrm{ml}$ of $2 \mathrm{~N}$ Hydrochloric acid was added and refluxed for $30 \mathrm{mins}$ at $1 \mathrm{c}$. The resultant solution was diluted to obtain (10ppm) solution and $10 \mu \mathrm{l}$ solutions were injected into the system and the chromatograms were recorded to assess the stability of sample.

\section{Alkali Degradation Studies:}

To $1 \mathrm{ml}$ of stock solution Anastrozole $1 \mathrm{ml}$ of $2 \mathrm{~N}$ sodium hydroxide was added and refluxed for $30 \mathrm{mins}$ at $60^{\circ} \mathrm{c}$. The resultant solution was diluted to obtain $(10 \mathrm{ppm})$ solution and $10 \mu \mathrm{l}$ were injected into the system and the chromatograms were recorded to assess the stability of sample.

\section{Dry Heat Degradation Studies:}

The standard drug solution was placed in oven at $105^{\circ} \mathrm{c}$ for $6 \mathrm{~h}$ to study dry heat degradation. For HPLC study, the resultant solution was diluted to $(10 \mathrm{ppm})$ solutionand $10 \mu 1$ were injected into the system and the chromatograms were recorded to assess the stability of the sample.

\section{Photo Stability studies:}

The photochemical stability of the drug was also studied by exposing the (100ppm) solution to UV Light by keeping the beaker in UV Chamber for 7days or $200 \mathrm{Watt}$ hours $/ \mathrm{m}^{2}$ in photo stability chamber For HPLC study, the resultant solution was diluted to obtain (10ppm) solutions and $10 \mu 1$ were injected into the system and the chromatograms were recorded to assess the stability of sample.

\section{Neutral Degradation Studies:}

Stress testing under neutral conditions was studied by refluxing the drug in water for 6hrs at a temperature of $60^{\circ} \mathrm{c}$. For HPLC study, the resultant solution was diluted to (10ppm) solution and $10 \mu \mathrm{l}$ were injected into the system and the chromatograms were recorded to assess the 
stability of the sample.

Table 10: Degradation Data of Anastrozole

\begin{tabular}{llll}
\hline S.NO & $\begin{array}{l}\text { Degradation } \\
\text { Condition }\end{array}$ & $\begin{array}{l}\text { \% Drug UN } \\
\text { Degraded }\end{array}$ & $\begin{array}{l}\text { \% Drug } \\
\text { Degraded }\end{array}$ \\
\hline 1 & Acid & 92.95 & 7.05 \\
2 & Alkali & 93.15 & 6.85 \\
3 & Oxidation & 95.55 & 4.45 \\
4 & Thermal & 97.44 & 2.56 \\
5 & UV & 98.40 & 1.60 \\
6 & Water & 99.14 & 0.86 \\
\hline
\end{tabular}

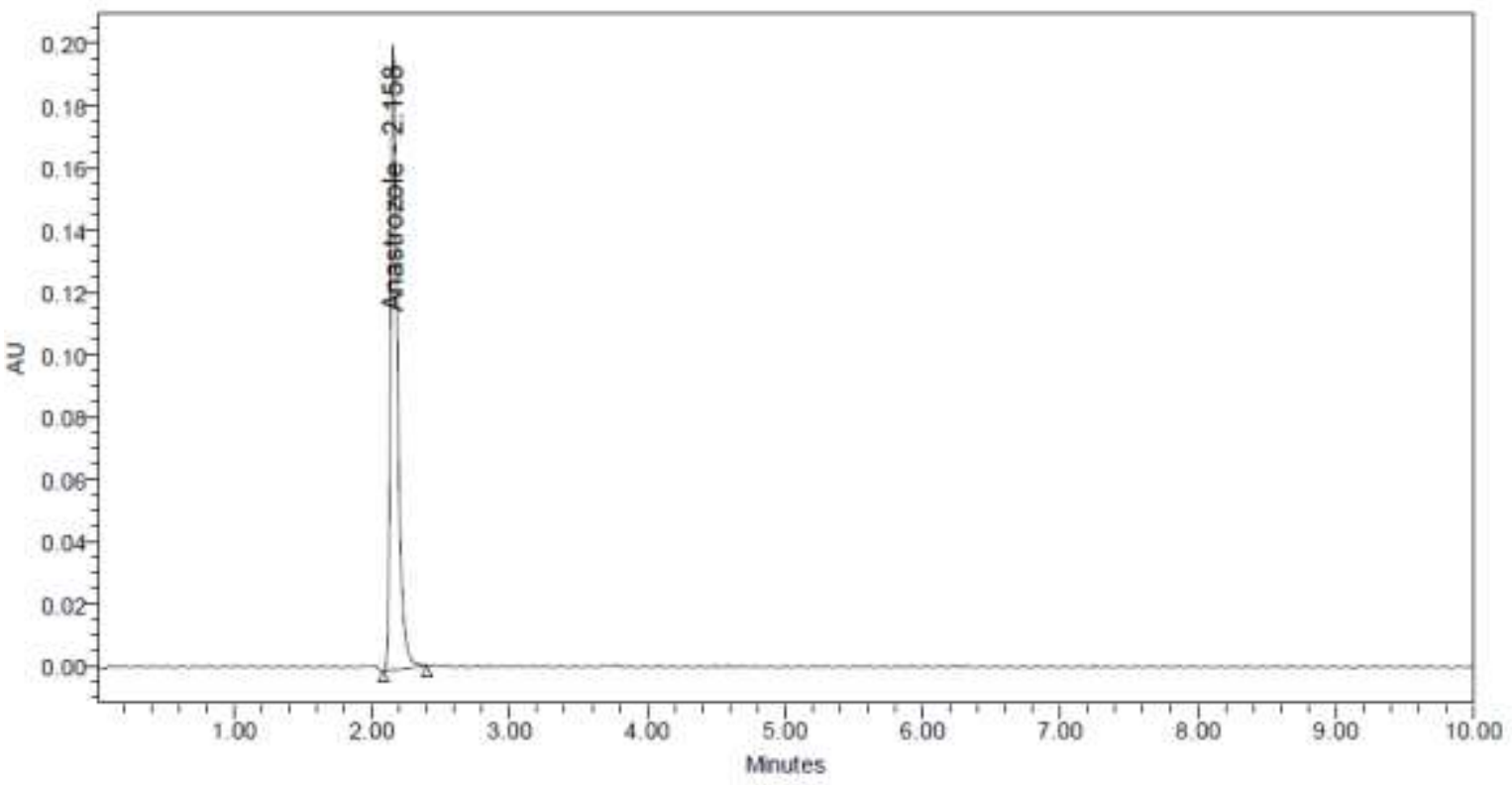

Acid degradation chromatogram

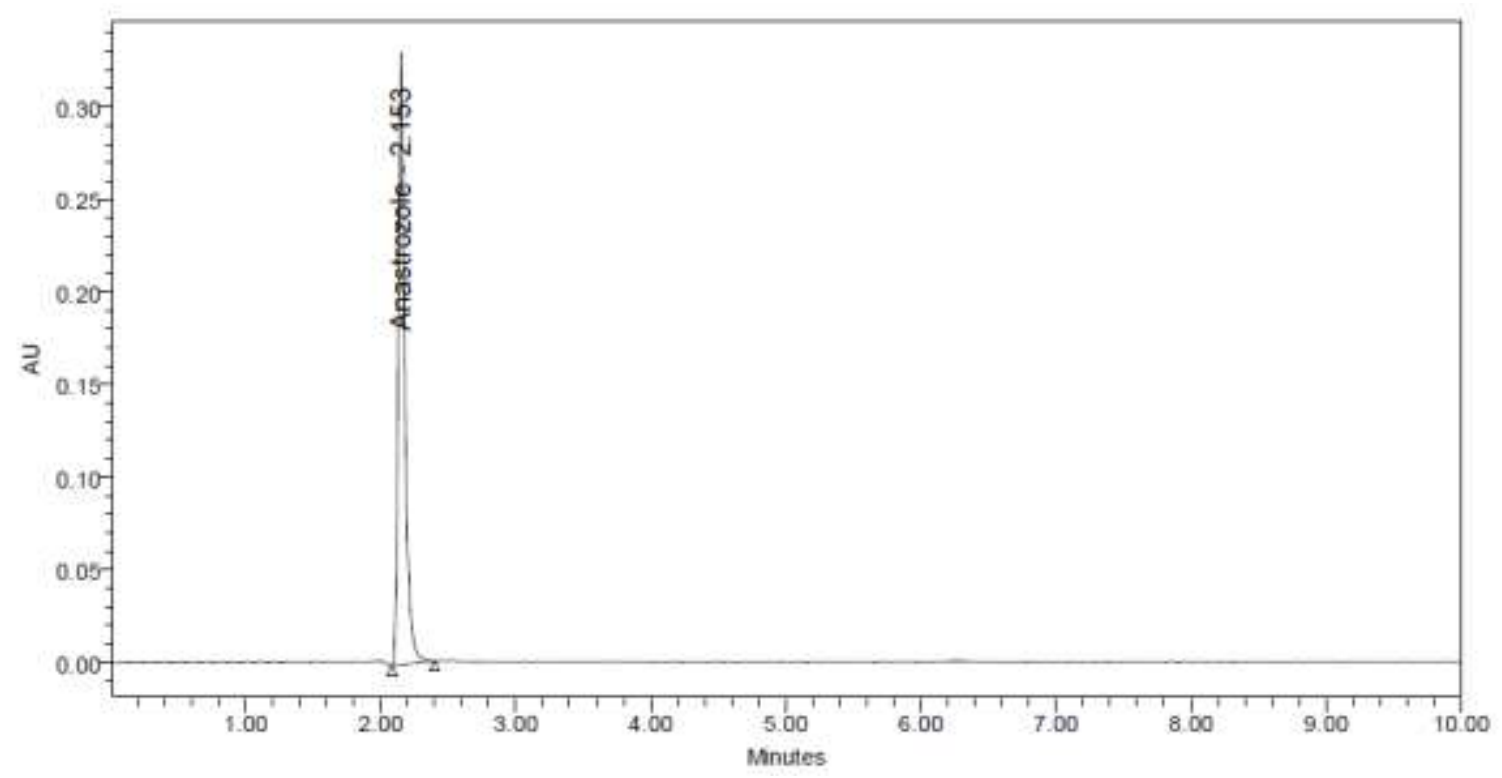

Base degradation chromatogram 
Table 11: Summary of validated parameters for proposed method:

\begin{tabular}{|c|c|c|c|c|}
\hline \multicolumn{2}{|l|}{ Parameters } & Anastrozole & \multicolumn{2}{|l|}{ Limit } \\
\hline \multicolumn{2}{|c|}{ Linearity :Range $(\mu \mathrm{g} / \mathrm{ml})$} & $2.5-15 \mu \mathrm{g} / \mathrm{ml}$ & $\mathrm{R}<1$ & \\
\hline \multicolumn{2}{|c|}{ Regression coefficient } & 0.999 & & \\
\hline \multicolumn{2}{|l|}{ Slope $(m)$} & 10800 & & \\
\hline \multicolumn{2}{|l|}{ Intercept(c) } & 445.0 & & \\
\hline \multicolumn{2}{|c|}{ Regression equation $(\mathrm{Y}=\mathrm{mx}+\mathrm{c})$} & $y=10800 x+445.0$ & & \\
\hline \multicolumn{2}{|c|}{ Assay(\% mean assay) } & $100.11 \%$ & \multicolumn{2}{|l|}{$90-110 \%$} \\
\hline \multicolumn{2}{|l|}{ Specificity } & Specific & \multicolumn{2}{|c|}{ No interference of any peak } \\
\hline \multicolumn{2}{|c|}{ System precision \% RSD } & 1.4 & \multicolumn{2}{|l|}{ NMT $2.0 \%$} \\
\hline \multicolumn{2}{|c|}{ Method precision \%RSD } & 0.5 & \multicolumn{2}{|l|}{ NMT $2.0 \%$} \\
\hline \multicolumn{2}{|c|}{ Accuracy \%recovery } & $100.20 \%$ & \multicolumn{2}{|l|}{$98-102 \%$} \\
\hline \multicolumn{2}{|l|}{ LOD } & 0.08 & \multicolumn{2}{|l|}{ NMT 3} \\
\hline \multicolumn{2}{|l|}{ LOQ } & 0.26 & \multicolumn{2}{|l|}{ NMT 10} \\
\hline \multirow[t]{6}{*}{ Robustness } & FM & 1.0 & & \\
\hline & $\mathrm{FP}$ & 1.4 & \multirow[t]{5}{*}{$\%$ RSD NMT } & \multirow[t]{5}{*}{2.0} \\
\hline & MM & 0.8 & & \\
\hline & MP & 1.4 & & \\
\hline & $\mathrm{TM}$ & 1.3 & & \\
\hline & $\mathrm{TP}$ & 1.1 & & \\
\hline
\end{tabular}

\section{SUMMARY AND CONCLUSION}

Chromatographic conditions used are stationary phase Azilent C18 (150mm*4.6mm $5 \mu \mathrm{m})$, Mobile phase $0.01 \mathrm{~N}$ kh2po4: Acetonitrile in the ratio of 60:40 and flow rate was maintained at $1.0 \mathrm{ml} / \mathrm{min}$, detection wave length was $215 \mathrm{~nm}$, column temperature was set to $30^{\circ} \mathrm{C}$ and diluent was mobile phase Conditions were finalized as optimized method. System suitability parameters were studied by injecting the standard six times and results were well under the acceptance criteria. Linearity study was carried out between $25 \%$ to $150 \%$ levels, $\mathrm{R}^{2}$ value was found to be as 0.999 . Precision was found to be 0.5 for repeatability and 0.6 for intermediate precision. LOD and LOQ are $0.086 \mu \mathrm{g} / \mathrm{ml}$ and $0.261 \mu \mathrm{g} / \mathrm{ml}$ respectively. By using above method assay of marketed formulation was carried out $100.11 \%$ was present. Degradation studies of Anastrozole were done, in all conditions purity threshold was more than purity angle and within the acceptable range. Full length method was not performed; if it is done this method can be used for routine analysis of Anastrozole.

\section{REFERENCE}

1. Divya T ,Pavani et al.., Method Development And Validation Of Anastrozole In Tablet Dosage Form By RP-HPLC Method, Journal of Global Trends in Pharmaceutical Sciences, 2017; 8(3): 4191-4197 M. B.

2. Abubaka et al., A Review of Chromatographic Methods Used in the Determination of 
Anastrozole Levels, Indian J Pharm Sci, 2016; 78(2) :173-181

3. P. Ravisankar and G. Devala Rao et al.., A novel validated RP-HPLC method for the determination of Anastrozole in bulk and pharmaceutical tablet dosage forms, Scholars Research Library 2013, 5(3):51-62

4. K. Krishnaveni et al., "Stability indicating RP-HPLC method development and validation for determination of Anastrozole in API and Pharmaceutical Dosage Form”, International Journal of Pharma Sciences, 2013; 3(6): 375-380.

5. V.N. Daphal et al., "Method Development and Validation of Simultaneous estimation of Anastrozole and Temozolomide in tablet Dosage Forms", International Journal of Theoretical \& Applied Sciences, IJTAS, 2012; 4(2): 48-55.

6. D.SATHIS KUMAR et al.., Development and Validation of a HPLC Method for

7. Determination of Anastrozole in Tablet Dosage Form, E-Journal of Chemistry2011, 8(2), 794-7

8. S. Kumar, A. Harani, R. Reddy, G. Sucharitha, P. Sagar, International Journal of Advances in Pharmaceutical Sciences, 2011,1(3), 329-333.

9. D.S. Kumar, A. Harani, D. Sridhar, D. Banji, K. Rao, Y. Aran, Journal of Chemistry, 2011, 8(2), 794-797. [18]

10. Malvia R, Bansal V, Pal O.P and Sharma P.K. A Review of High Performance Liquid Chromatography. Journal of Global Pharma technology (2010)

11. Y.R. Reddy, S.R. Nandan, D.V. Bharathi, B. Nagaraju, S.S Reddy, L.K. Ravindranath, V.S. Rao, Journal of pharmaceutical and biomedical analysis, 2009, 50(3), 397-404.

12. The United States Pharmacopoeia- the National Formulary, United States Pharmacopoeial convention, Rockville, 2007.

13. Gurdeep R.Chatwal, Sham K .Anand, Instrumental Methods of Chemical Analysis, Pg 2.566-2.638 (2007)

14. B.k Sharma, Instrumental methods of chemical analysis, Introduction to analytical chemistry, 23rd Edition Goel publication , Meerut, (2007)

15. G.Saravanan,M.V. Suryanarayana, M.J. Jadhav, M. Ravikumar, N. Someswararao, and P.V.R Acharyulu, Chromatographia, 2007, 66(5-6), 435-438.

16. British Pharmacopoeia, the Stationary Office, London, 2005.

17. ICH Harmonised Tripartite Guideline. (2005). Validation of analytical procedures: Text and methodology, Q2 (R1). International Conference on Harmonization,

18. Nasal.A, Siluk.D, and Kaliszan.R. Chromatographic Retention Parameters in Medicinal 
Chemistry and Pharmacology, Pubmed, Vol.10, Issue 5 Pg no-381-426, March (2003)

19. Remington's The Sciences and Practice of Pharmacy, 20th Edition (2000)

20. https://www.drugbank.ca/drugs/DB01217.

21. https://pubchem.ncbi.nlm.nih.gov/compound/Anastrozole.

22. https://www.scbt.com/p/anastrozole-120511-73-1.

23. https://www.ncbi.nlm.nih.gov/pubmed/9805213.

24. Douglas A Skoog, F. James Holler, Timothy A. Niemen, Principles of Instrumental Analysis Pg 725-760.

25. Indian Pharmacopoeia, Ministry of Health \& Family Welfare, Government of India, New Delhi, 1996.

26. David G. Watson. Pharmaceutical Analysis, A text book for Pharmacy students and Pharmaceutical Chemists. Harcourt Publishers Limited; 2nd Ed., Pg 221-232.

27. Connors Ka. A Textbook of Pharmaceutical Analysis, Wiley inter sciences Inc; Delhi, 3rd Ed, Pg 373-421, (1994). 